\section{Theorising about human occupation}

- his special edition presents contributions from local and international occupational scientists, occupational therapy researchers, academics and practitioners. The papers demonstrate how theorising about human occupation has translated into research, practice and curricula reform, spanning four continents. The edition comes at an important time in the history of occupational therapy in South Africa as the country prepares to host the first ever conference of the World Federation of Occupational Therapists in Africa, during 2018. An exciting opportunity exists to articulate what an occupation-centered practice of occupational therapy may entail at this historical juncture, through harnessing the wealth of knowledge, expertise and development thinking in the South'. The process of explicating the theoretical substance of southern occupational therapy practices coincides with the growing integration of occupational science into occupational therapy programmes nationally.

Occupational science is regarded as the site for theorising and interdisciplinary research aimed at understanding the form, function and meaning of human occupation ${ }^{2,3}$. The initial concern driving the inception of this discipline was to inform and validate occupational therapy practice 4 . Others however, have argued that scholarship and theorising about humans as occupational beings, has always been embedded within occupational therapy as a practice profession ${ }^{5}$. Yet theorising or what is done to produce theory is a distinct scholarly practice. It is an endeavor that is critical for growing and deepening scholarship within any profession and cognate disciplines. Most professions and disciplines however pay more attention to theories that already exist rather than the actual process of producing theory. In sociology and social science for instance, Swedberg 6 noted greater emphasis on existing theories such as those generated by Durkeim, Weber and Bourdieu and sustained neglect of theorising as a scientific attitude that could be learnt. What constitutes a theory is also poorly understood across many disciplines and professions, with conceptual models or frameworks often treated the same way a theory would. These terms tend to be erroneously used interchangeably within professional discourse. For a relatively young profession such as occupational therapy, and for occupational science as a new discipline, it is imperative that such errors are addressed, in order to build a solid theoretical foundation for both the discipline and the profession.

There are interesting parallels to be drawn between theory developments in sociology and social science and our own discipline and profession, given that 'action'; a sociological concept, is inferred in the term 'occupation', a central focus in both the profession of occupational science and the profession of occupational therapy. A theory is defined in social science as a system of interconnected ideas that helps explain how a particular aspect of the social world works and why ${ }^{7}$. To produce a theory is an elaborate process, with some basic rules to be observed, yet also space for intuition and some creativity ${ }^{6}$. While theories serve both an explanatory or predictive role in most disciplines, there are limitations when it comes to human behavior or action, where context plays a critical role ${ }^{8}$. To emphasise this point, Flyvbjerg argues that "....as for predictive theory, universals, and scientism, the study of human affairs is, thus, at an eternal beginning'8:224. The existence of a theory, however, should be viewed as a second phase of the scientific enterprise ${ }^{6}$. This stage is preceded by the act of theorising, located within the context of discovery. The third element, which lies in the context of justification, is the testing of theory. Much of the work of sociologists and social scientists in the last 50 years has emphasised theory justification. The difference between these disciplines and our own discipline and profession however, is that we may not even have our own theories to begin with. It seems prudent and an urgent necessity for occupational science and occupational therapy therefore, to invest in theorising about human occupation as an act of dis- covery, even as some concepts would be borrowed from other disciplines.

Theorising, in the context of discovery as described by Swedberg 6 with reference to sociology and social science, is made up of (I) observation, (2) the naming or formulation of the central concept, (3) the building out of the theory and lastly, (4) the formulation of a tentative theory, including the explanation ${ }^{6}$. This process may be a useful one to consider in theorising about human occupation. Notwithstanding the on-going global debate about the legitimate place within which to theorise about human occupation, a critical concern regards the extent to which occupational constructs or concepts as well as theory inform and advance occupational therapy research, practice and curricula.

This special edition recognises that much work has been accomplished locally and internationally in growing occupational science as a distinct interdisciplinary and scientific body of knowledge, as well as in expanding occupational therapy practice models and conceptual frameworks. Critical studies of human occupation have also emerged from South America in particular, noting other sources alongside scientific knowledge, as credible sites of learning and knowing about human occupation. This rich conceptual foundation has served to expand occupational therapy practice, beyond the traditional confines of clinical settings, to embrace the social practice of occupational therapy where individuals live, learn, work and play. Research in occupational therapy has also grown to embrace emerging occupational science constructs, with critical questions regarding our impact on society, and honest interrogation concerning our everyday professional practice and education.

Reflecting on the historical conditions that shape occupational therapy as an institution in South America and Africa, Guajardo, Kronenberg and Ramugondo argue for professional identities, epistemologies and practices that position occupational therapy within social transformation". Their call for southern theorising is substantiated by the need for critical professional engagement with those groups and identities that are excluded through the hegemonic conception of society ${ }^{10}$. Using the American Civil Rights Movement and the South African Struggle against Apartheid as the context of discovery, Frank and Murithi demonstrate occupational science theorising about the occupational dimensions of social transformation ". They describe a system of interconnected ideas to arrive at a theory of occupational reconstructions that seeks to explain what people do to remake ordinary life in response to a problematic social situation. Kronenberg, Kathard, Laliberte Rudman and Ramugondo use post-apartheid South Africa as an exemplar of a society in crisis ${ }^{12}$. They propose and theorise a process through which pervasive dehumanisation dynamics can be defeated on a day-to-day basis through human occupation and suggest that compliance with the unique philosophical attributes of the African continent will enable occupational therapists and occupational scientists to generate practical knowledge that will enable society to humanise and heal itself. Laliberte Rudman draws attention to social-political relations of power when theorising socially transformative practice ${ }^{13}$. She explores how power operates through ageism in ways that shape what people come to take for granted regarding occupation in relation to age. Drawing on the stories of three marginalised women who abuse alcohol during pregnancy, Cloete and Ramugondo provide evidence for theorising the ways in which structural entrenchment, as a feature of inter-generational poverty, may lead to imposed occupations ${ }^{14}$. They point to the need for theorising that takes account of the historical, cultural, economic and political conditions that perpetuate occupational inequities. In addressing the relationship between privilege and occupational justice, Galvaan, Peters, Smith, Brittain, Menegaldo, Rautenbach and Wilson-Poe illustrate the power of understanding lived narratives in theory building ${ }^{15}$. They explain how relational power in occupational engagement contributes to 
privileges and opportunities for some, which may create conditions contributing to occupational injustice. Ikiugu, Hoyme, Muller and Reinke problematise the assumptions held about 'meaningful occupation' as a therapeutic catalyst for health and well-being ${ }^{16}$. They make a distinction between meaningful and psychologically rewarding occupations and propose that both types of occupations are necessary to optimise the benefits of occupational therapy. Gretschel, Ramugondo and Galvaan introduce cultural historical activity theory (CHAT) as a lens for understanding the design of interventions as an occupation of occupational therapists ${ }^{17}$. They demonstrate how CHAT allows for the discovery and analysis of the potential enablers and barriers to innovative, relevant and critically considered occupational therapy interventions in the South African context. This special edition concludes with two articles that focus on human occupation in the curriculum. Aldridge introduces a northern perspective on the use of technology supported pedagogical platforms to facilitate undergraduate students' understanding of human occupation ${ }^{18}$. She describes an occupational science course that used synchronous online interactions and reflective opportunities between United States and Swedish students to enable experiential learning about occupation from a local and global perspective. Green, Hudson, Wicht, Willows and Buchanan describe the impact of two modules on first year occupational therapy students' knowledge and attitudes to the core constructs of occupation ${ }^{19}$. They illustrate the value of using an existing conceptual model to ground undergraduate learning of the relationships between occupation, the person and the environment and to recognise the influences these may have on occupational performance.

The purpose of this special edition is to pave the way for intensified theorising about human occupation and occupation centered practice in anticipation of the WFOT 2018 congress in Cape Town. It turns our attention to the needs of people in the majority world as they pursue the lives they have reason to value'. The articles illustrate the intrinsic complexity of human occupation and the growing commitment of occupational therapists and occupational scientists to advance its connection with fairness and justice in the world. Theorising human occupation can contribute to human development by providing theories to guide how we engage in occupational therapy practices that promote lives that people have reason to value.

\section{REFERENCES}

I. Malik K. Human Development Report 2013. The rise of the South: Human progress in a diverse world. New York, United States of America: United Nations Development Programme, 2013.

2. Clark FA, Parham D, Carlson ME, Frank G, Jackson J, Pierce D,... Zemke R. Occupational science: Academic innovation in the service of occupational therapy's future. American Journal of Occupational Therapy, 1991; 45(4): 300-310.

3. Yerxa EJ. An introduction to occupational science: A foundation for occupational therapy in the 21 st century. Occupational Therapy in Health Care, 1990; 6(4): I-I7.

4. Yerxa E. Occupational science: A new source of power for participants in occupational therapy. Journal of Occupational Science, 1993; I (I): 3-9.

5. Nelson DL. Why the profession of occupational therapy will flourish in the 21 st Century: 1996 Eleanor Clarke Slagle Lecture. 1996. <http://www.aota.org/-/media/Corporate/Files/Publications/AJOT/ Slagle/a996.ashx> (18 March 2105).

6. Swedberg R. Theorizing in sociology and social science: turning to the context of discovery. Theory \& Society, 20I2; 4I(I): I-40.

7. Neuman WL. Social research methods: Qualitative and quantitative approaches (7th Ed.). Boston, MA: Pearson, 20I I.

8. Flyvbjerg B. Five misunderstandings about case-study research. Qualitative Inquiry, 2006; 12(2): 219-245.

9. Guajardo A, Kronenberg F, Ramugondo, E.L. Southern occupational therapies: Emerging identities, epistemologies and practices. South African Journal of Occupational Therapy, 2015; 45(I): In this edition.

10. Connell R. Southern theory: the global dynamics of knowledge in social science. Cambridge: Polity Press, 2007.

II. Frank G, Murithi BAK. Theorising social transformation in occu- pational science: The American Civil Rights Movement and South African Struggle against Apartheid as 'occupational reconstructions'. South African Journal of Occupational Therapy, 20I5; 45(I): In this edition.

12. Kronenberg K, Kathard H, Laliberte Rudman D, Ramugondo E.L Can Post-Apartheid South Africa be enabled to humanise and heal itself? South African Journal of Occupational Therapy, 20I5; 45(I): In this edition.

13. Laliberte Rudman D., South African Journal of Occupational Therapy, 2015; 45(I): In this edition.

14. Cloete LG, Ramugondo E.L "I drink": Mothers' alcohol consumption as both individualised and imposed occupation. South African Journal of Occupational Therapy, 2015; 45(I): In this edition.

15. Galvaan R, Peter L, Smith T, Brittain M, Menegaldo M, Rautenbach N, Wilson-Poe A. Employers' experiences of having a live-in domestic worker: Insights into the relationship between privilege and occupational justice. South African Journal of Occupational Therapy, 20I5; 45(I): In this edition.

16. Ikiugu MN, Hoyme AK, Mueller BA, Reinke RR. Meaningful occupation clarified: Thoughts about the relationship between meaningful and psychologically rewarding occupations. South African Journal of Occupational Therapy, 2015; 45(I): In this edition.

17. Gretschel P, Ramugondo EL, Galvaan R. South African Journal of Occupational Therapy, 20I5; 45(I): In this edition.

18. Aldrich RM. Course redesign to promote local and global experiential learning about human occupation: Description and evaluation of a pilot effort. South African Journal of Occupational Therapy, 2015;45(I): In this edition.

19. Green H, Wicht M, Willows C, Buchanan H. The impact of two modules on first year occupational therapy students' knowledge and attitudes to the core constructs of occupation. South African Journal of Occupational Therapy, 20I5; 45(I): In this edition.

http://dx.doi.org/| 0.17 I 59/23 I 0-3833/20 I 5/v45no I a I

EL Ramugondo; R Galvaan; E Duncan 